○特集 $\mid$ メンブレン・ストレスバイオテクノロジー

\title{
モデル生体膜ミクロ相分離構造の解析
}

\author{
大木和夫 \\ 東北大学 大学院理学研究科 物理学専攻 \\ 干 980-8578 宮城県仙台市青葉区荒巻字青葉 6-3
}

\section{Analysis of Micro Phase Separation in Biomembrane Model}

\author{
Kazuo Ohki \\ Department of Physics, Tohoku University \\ Aoba-ku, Sendai 980-8578, Japan
}

The cell is a system in which large number of various functions are integrated into the micrometer scale. And the formation of the phase-separated micro domains plays an important role for this integration to make heterogeneous regions in a small area. Indeed, phase-separated micro domain, 'raft' was found in plasma membrane of a cell. Important biological functions such as GPI-anchored protein and virus receptor are located in the raft. In order to investigate phase-separated micro domains, the authors have developed microscopic imaging instrument using environment sensitive fluorescence dye, laurdan. The instrument was applied to a model of raft, which elucidated enzymic conversion of sphingomyelin to ceramide destroyed phase-separated micro domains.

Key words : micro domain / phase separation / liquid ordered phase / raft $/$ biomembrane

\section{1.はじめに}

生体膜は蛋白質と脂質を主要な構成成分とし，そ の機能は DNA上の遺伝情報による直接の産物である 蛋白質が担っている. 一方, 膜蛋白質の活性には脂 質が要求される. 生体膜の基本構造となる脂質二重 層膜は膨大な数の脂質分子が水中で集合して形成し, 相転移，相分離などの統計熱力学的な物性とともに 流動的な物性も示す. 膜蛋白質の生物機能と活性は 脂質との相互作用を通じて影響を受けることになる. これは生体膜の機能制御機構と捉えることができる.

Tel : 022-795-6464

Fax :022-795-6774

E-mail : ohki@bio.phys.tohoku.ac.jp
2. 細胞の温度適応機構における細胞膜の相 転移，膜流動性および相分離

細胞の温度適応と生体膜の相転移温度が相関して いることは枯草菌 ${ }^{1)}$, シアノバクテリア ${ }^{2)}$, テトラヒ メナ3）などで, また, 膜流動性との相関は大腸菌 ${ }^{4)}$, テトラヒメナ 5) などで報告されている. 地球上の生 命の基本単位である細胞では膨大な数の化学反応が 行われており, 生体膜はその区画性と選択的な透過 性で化学反応の基質と生成物が代謝経路の中で存在 する場所を制御している。そのための多様な機能が 微小な生体膜上に分布している. 相分離は物性が異 なる領域が共存しており, 多様な機能を存在させる には好都合である，そこで, 相分離が生体膜で生じ ることを, 相分離が相転移と相関した現象であるこ とを用いて観察している (Fig. 1)。テトラヒメナ細 胞の培養温度を低温にシフトさせると相転移に伴っ 


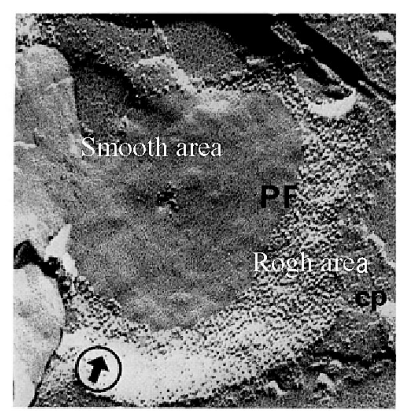

Fatty acid composition $\begin{array}{ccc}\text { Smooth area } & \text { Rough area } \\ \text { C14:0 } & 9.3 & \end{array}$ C16:0 $24.4>19.3$ $\begin{array}{lll}\mathrm{C} 18: 0 & 1.3 & 1.6\end{array}$ $\begin{array}{lll}\mathrm{C} 16: 1 & 8.4 & 8.0\end{array}$ C18:1 $17.6<19.3$ $\mathrm{C} 18: 2 \quad 14.7<19.0$ C18:3 $11.3<15.5$

Fig. 1 Phase separation in Tetrahymena membrane Tetrahymena cells were supplemented with palmitic (C16 : 0) acid. To induce phase separation, the growth temperature was lowered from $39.5^{\circ} \mathrm{C}$ to $15^{\circ} \mathrm{C}$. The cells were fragmented by homogenizer and microsomes were obtained by centrifugation. The microsomes were observed by freeze-fracture electron microscope. Alternatively, microsomes were sonicated and then separated by density gradient centrifugation. Fatty acid composition of each fraction was analyzed by gas-liquid chromatograph. Unsaturated fatty acids were rich in the rough area containing membrane protein and saturated fatty acids were rich in protein free smooth area.

て生体膜に相分離が誘導されるが，その変化を強調 して観察するために飽和脂肪酸のパルミチン酸を添

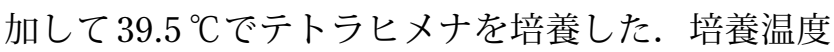
を $15{ }^{\circ} \mathrm{C}$ に低下させて, 分画した小胞体を凍結割断電 子顕微鏡で観察した。すると膜蛋白質が存在しない 滑らかな領域と膜蛋白質の顆粒が存在する粗い領域 への相分離が観察された ${ }^{6)}$.この小胞体を超音波処理 で破砕し, 密度勾配遠心で密度の低い脂質画分（滑 らかな領域）と密度の高い蛋白質を含む画分（粗い 領域）に分離しその脂質組成を分析した。 その結果, 相転移温度が高い飽和脂肪酸をもつリン脂質が温度 の低下によりゲル相に転移し，膜蛋白質を不飽和脂 肪酸をもつリン脂質領域に排除したことが示された (Fig. 1).

\section{3. ミクロ相分離構造としてのラフト}

生体膜でのミクロ相分離構造はラフト（raft）とし て知られている．細胞の形質膜に非イオン性の界面 活性剂 Triton X-100に低温（ $4^{\circ} \mathrm{C} ）$ では不溶な膜 （Detergent resistant membrane, DRM）画分が発見さ れ，コレステロール，スフィンゴ脂質，スフィンゴ 糖脂質が多く含まれていた。脂質膜の海を漂う筏の イメージからラフトと名付けられた。 ラフトには GPI 結合蛋白質が集積し, 細胞の情報伝達の部位で

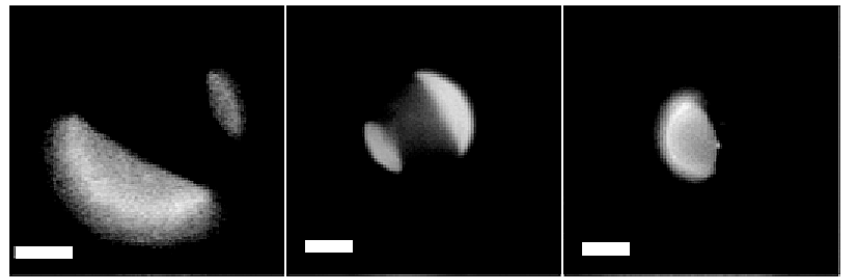

Fig. 2 Microscopic observation of raft model.

Giant uni-lamellar vesicle (GUV) composed by cholesterol, dioleoylphosphatidylcholine (DOPC) and $N$-palmitoyl-D-erythro-sphingosylphosphorylcholine (C16-SM) (1:1:1, molar ratio). The GUV contains $0.1 \mathrm{~mol} \%$ of 1,2 -dihexadecanoyl-sn-flycero3-phosphoethanolamine conjugated with Texas Red-dipalmitoylphosphatidylethanolamine (TR-DPPE). Observations were performed at room temperature $\left(22 \sim 25^{\circ} \mathrm{C}\right)$. Bright regions indicate liquid disordered phase and dark regions indicate liquid ordered phase. Scale bars were $10 \mu \mathrm{m}$.

あるとともに, ウィルスの受容体が集積している. ラフトについてはその細胞上での機能の重要性が指 摘され ${ }^{7)}$, 精力的な研究が進められており, 生体膜上 でミクロ相分離構造を形成する機構と特定の機能を 担う蛋白質を集積する機構の解明が必要である. コ レステロールはラフトの相分離構造では重要な役割 を果たして抢り，ジパルミトイルホスファチジルコ リン（DPPC）の相転移ではゲル相と液晶相でその作 用は反対の効果を示し, ゲル相を液晶相に, 液晶相 をゲル相に近づけ中間的な状態を形成する。この中 間状態は液晶秩序相（liquid ordered phase）と名付 けられたが 8)，これがラフトの相分離構造に対応する ものであった．コレステロールが誘導するミクロ相 分離構造は脂質組成との関係が研究され, 赤血球膜 内層の脂質組成をコレステロール/スフィンゴミエリ ン/ホスファチジルコリン/ホスファチジルエタノー ルアミン/ホスファチジルセリン/Texas Red-dimyristoylphosphatiydlethanolamine (TR-DMPE) (46.2 : $5.3: 7.4: 28.4: 12.5: 0.2)$ で模倣して単分子膜を調製 し, 蛍光標識脂質の TR-DMPEが液体非秩序相に分 布することを顕微鏡で観察している. $23^{\circ} \mathrm{C} て ゙$ 表面圧 が $18.5 \mathrm{dyn} / \mathrm{cm}$ のとき蛍光脂質が存在する液体非秩序 相と存在しない液体秩序相への相分離が観察され た ${ }^{9}$. ラフトの形成にはコレステロールが必須であり, 各種脂肪酸構成のホスファチジルコリンとホスファ チジルエタノールアミン, ホスファチジルセリンに スフィンゴミエリンを加えた 14 種の組み合わせでコ レステロールの分配率を測定した結果，スフィンゴ ミエリンが含まれるときに高い分配率が示された ${ }^{10)}$. 


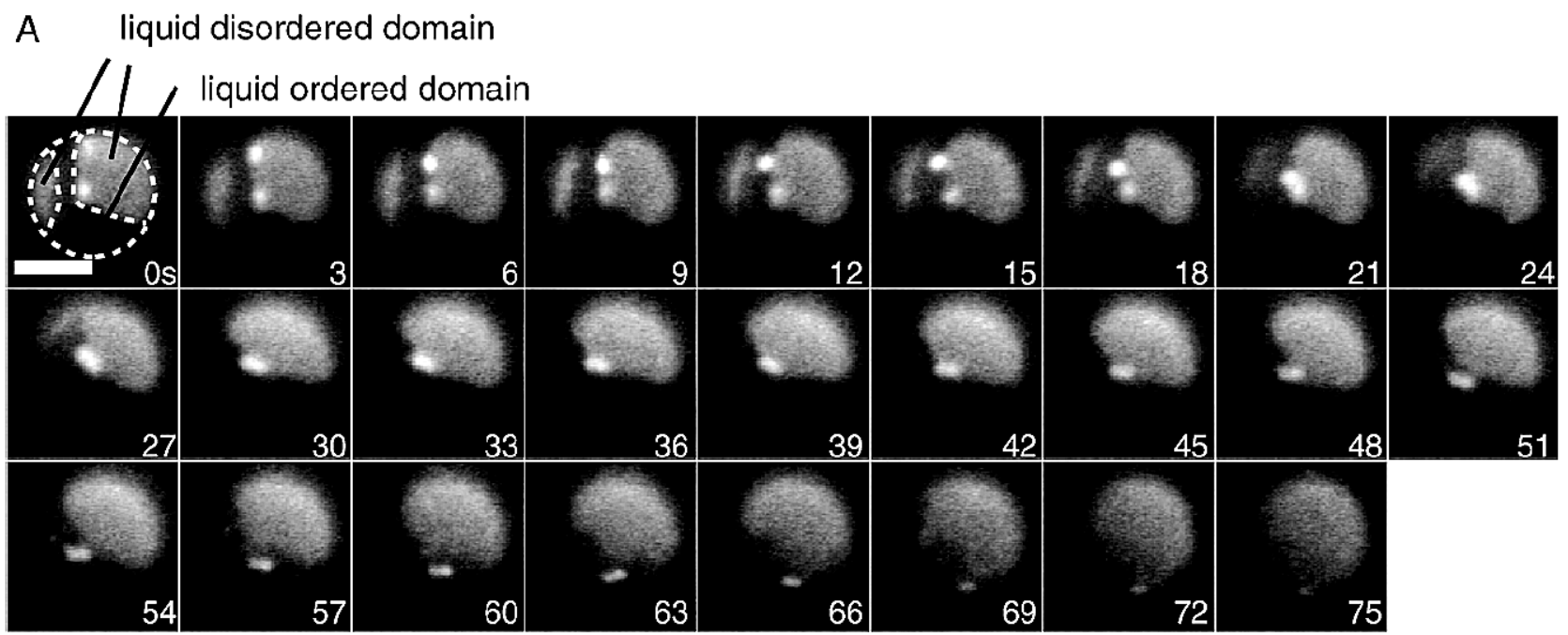

Fig. 3 Effect of sphingomyelinase treatment on raft model.

A sequence of images showing the process of sphingomyelinase-induced alteration of domain structure. Numbers in each panel show the time (sec) elapsed from the start of the record. Until 27s, two domains were apparent; during $27 \sim$ $33 \mathrm{~s}$ they fused to each other. Then, at $33 \mathrm{~s}$ domain boundary started undulating; it became noticeable at $39 \mathrm{~s}$. At $57 \mathrm{~s}$, TR-DPPE began to spread into the dark region. The dots were small vesicles attached on the larger vesicle. They showed Brownian movement (see Supplemental movie), which can represent surface movements. Initial composition of the GUV was DOPC/C16SM/cholesterol = 1: 1: 1 (molar ratio) $+0.1 \mathrm{~mol} \%$ TR-DPPE. Scale bars were $10 \mu \mathrm{m}$.

コレステロールとスフィンゴミエリンの特異的な相 互作用がミクロ相分離を形成するとの視点からコレ ステロールとスフィンゴミエリンの間に特異的な水 素結合が形成されると想像された。しかし，NMRを 使用した各原子間の相互作用を測定した実験ではそ のような結合を証明する結果は得られず,むしろ分 子全体で相互作用していると示唆された ${ }^{11)}$. コレス テロールとスフィンゴミエリンの特異的な相互作用 の機構の未解明にかかわらず，ミクロ相分離構造を 形成するラフトのモデル系での研究は広く行われて いる.

\section{4. ラフトの形成と消失の動的な過程と酵素 的な脂質変換による制御}

著者らはコレステロールとスフィンゴミエリンと ホスファチジルコリンの 3 成分系で巨大リポソームの ラフト・モデル系を調製した．液体秩序相の形成に よるミクロ相分離構造の顕微鏡下の観察では蛍光標 識リン脂質が液体非秩序相へ選択的に分配すること が利用されている．蛍光脂質の存在する明るい部分 が液体非秩序相で, 蛍光脂質の存在しない暗い部分 が液体秩序相となる（Fig. 2)。室温でミクロ相分離 構造が形成されるこのモデル系を用いて, 脂質構成 の酵素的な変換がミクロ相分離構造の形成と消失の 制御機構となる可能性について検討した ${ }^{12)}$. 細胞の
情報伝達機構ではホルモンや神経伝達物質が細胞表 面の受容体に結合するとホスホリパーゼCが活性化 されてイノシトールリン脂質を分解し，イノシトー ル 1，4，5-3 リン酸（IP3）とジアシルグリセロール （DG）を生成し，それぞれ小胞体からのカルシウム 動員とプロテインキナーゼCの活性化を行うことが 知られている ${ }^{13,14)}$. また, スフィンゴミエリンはス フィンゴミエリナーゼによりセラミドに変換されて アポトーシス（プログラム細胞死）のシグナルとな ることが知られており, この変換によりホスファチ ジルコリンと良い混合性（miscibility）をもつスフィ ンゴミエリンはセラミドになり混合性を大きく低下 させることが示された ${ }^{15)}$. そこで, ラフトのモデル 系にスフィンゴミエリナーゼを作用させてスフィン ゴミエリンがセラミドに変換される過程でミクロ相 分離構造がぞのように変化するかを顕微鏡下に観察 した (Fig. 3). その結果, 暗い液体秩序相と Texas Red-dipalmitoylphosphatiydlethanolamine (TRDPPE）が存在し明るい液体非秩序相が存在するミク ロ相分離構造にあるラフト・モデルで, 酵素処理に よりスフィンゴミエリンがセラミドに変換されるの に伴い暗い液体秩序相がその構造を緩和して TR-DPPEがその領域にも侵入し, 最終的に巨大リポ ソームの膜全体に TR-DPPEが分布してミクロ相分離 構造が消失した ${ }^{12}$. 著者らはミクロドメインや相分 離構造を蛍光脂質の分布ではなく, 相状態に依存し 

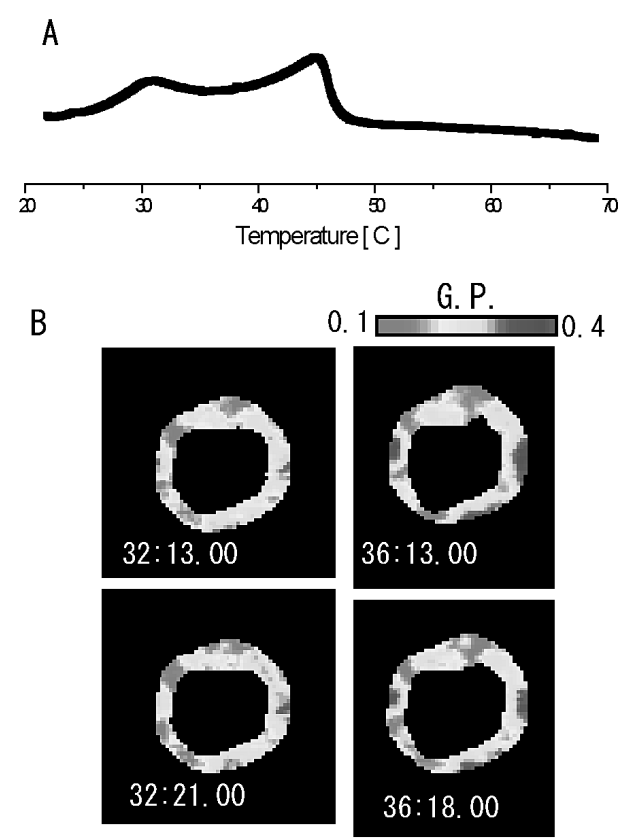

Fig. 4 Micro phase separation of equimolar binary mixture of DMPC and DMPE.

Liposomes of binary mixture of dimyristoyl (DMPC) and dimyristoylphosphatidylethanolamine (DMPE) were prepared by voltexing and electroformation for DSC measurement and microscopic observation, respectively. (A) Multi-lamellar vesicle of the binary mixture was measured by Privalov DASM-4 high sensitivity differential scanning calorymeter at heating scan rate at $0.5 \mathrm{~K} / \mathrm{min}$. (B) Giant liposome of the binary mixture was observed by home-built microscopic imaging instrument by laurdan. Time stamp (min : sec.00) of recording is shown in each image.

た膜内への水分子の分配から顕微鏡下に画像化する 装置を開発した。この装置では環境感受性蛍光色素 laurdanを使用しており，この色素はラウリル酸基を 側鎖にもち容易に生体膜・脂質膜に導入される．ま た，その発光波長は環境の極性により変化し，ジパ ルミトイルホスフアチジルコリン（DPPC）に導入し たときゲル相では水分子の浸入がないので, $440 \mathrm{~nm}$ に発光の極大を示すが, 流動相では水分子が浸入す るため溶媒緩和により極大が $490 \mathrm{~nm}$ にシフトする. この変化を Parassi らは Generalized Polarization (G.P.) として次のように定義している ${ }^{16)}$.

$$
G . P .=\frac{I_{440 \mathrm{~nm}}-I_{490 \mathrm{~nm}}}{I_{40 \mathrm{~nm}}+I_{490 \mathrm{~nm}}}
$$

この G.P.值の顕微鏡画像を得るために $440 \mathrm{~nm}$ と 490 $\mathrm{nm}$ の光路をダイクロイック・ミラーと単色フィルタ

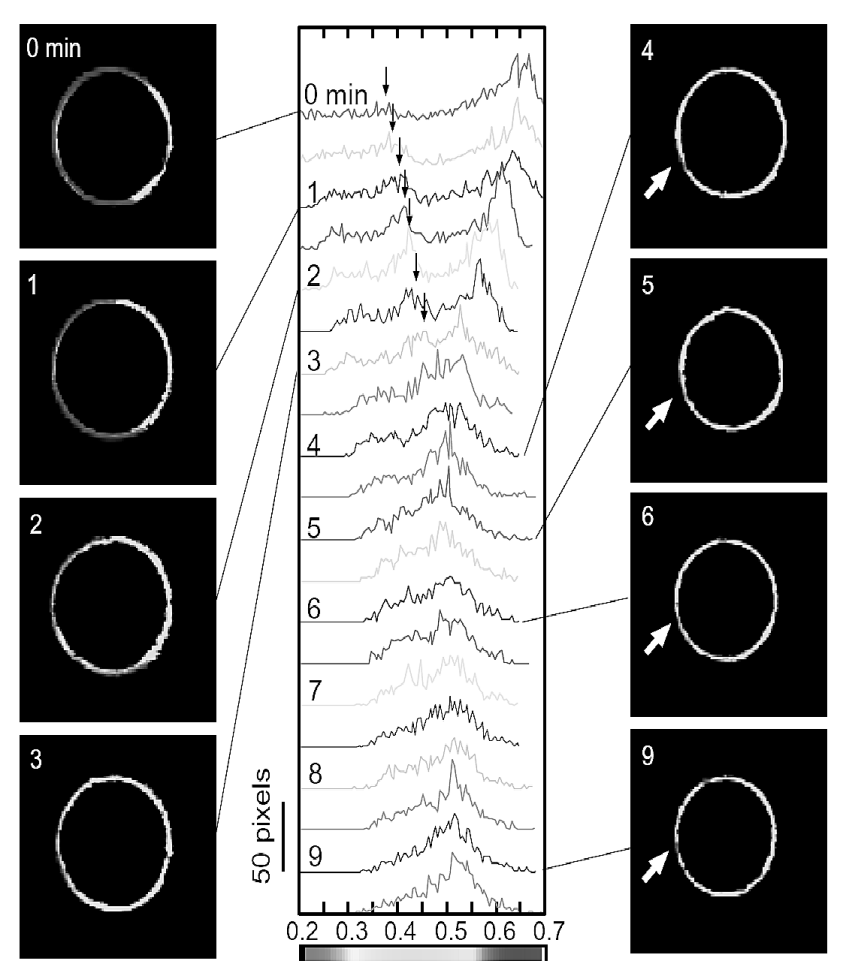

Fig. 5 Change of phase separated state in a raft model treated with sphingomyelinase.

Change of domain structure visualized with laurdan. The color images are GP-images calculated from the $440 \mathrm{~nm}$ and $490 \mathrm{~nm}$ images at indicated times from four minutes after the addition of sphingomyelinase. The middle column shows the change in the distribution of GP values of the contour of giant uni-lamellar vesicle of raft model composed of cholesterol/dioleoylphosphatidylcholine (DOPC) $/ \mathrm{C} 16 \mathrm{SM} /=1: 1: 1$ (molar ratio) $+1 \mathrm{~mol} \%$ laurdan.

一の組み合わせで分離し CCD カメラの受光面に並列 に両波長の光を結像させて録画する装置を開発した. さらに, ダイナミック・アフィン変換のプログラム を開発し, 両画像の位置を一致させて G.P.值の定義 にしたがった画像の演算で G.P.画像を求め, 脂質 2 成 分混合系でビデオレートの相分離を観察した ${ }^{17)}$. DMPC と DMPEが 1 対 1 の 2 成分系のDSC 測定では

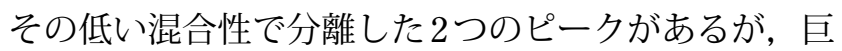
大リポソームを調製してこの装置で観察すると, 相 転移温度が高い DMPE $\left(\mathrm{T}_{\mathrm{m}}=49^{\circ} \mathrm{C}\right)$ はゲル相にあり, 固い直線となるが相転移温度の低い DMPC（Tm = $23^{\circ} \mathrm{C}$ ）は流動相にあり, 柔らかい蝶つがいとなって いることが示された（Fig. 4)。この装置を前述のラ フト・モデル系に適用し, 酵素処理による相分離状 態の解消を観察した（Fig. 5） ${ }^{12)}$. ラフト類似の脂質 組成で調製した巨大リポソームに環境感受性蛍光色 素laurdanを導入し，スフィンゴミエリナーゼでスフ 
インゴミエリンをセラミドに変換すると処理前には 液体秩序相に相当する高い G.P.值と非秩序相に相当 する低いG.P.值の 2 つ領域への分布が存在していた が, 処理後の時間経過にともない, 中間 G.P.值に分 布が移行した.これは脂質の変換によりミクロ相分 離構造が解消したことを示している.

\section{5. おわりに}

ラフトは細胞で外界の情報等を受容するミクロド メインであることが示され, 精力的な研究が進めら れている. 相分離という物理現象と直接に相関して おり, 生化学的な研究が先行している生命科学にお いて物性と細胞機能の関連を解明できる対象となっ ている. 生物が膜の物性的な特徴を利用してどのよ うに機能を実現しているかがミクロドメインの研究 から展開することを期待したい.

\section{文 献}

1) McElhaney RN, Souza KA : Biochim. Biophyhs. Acta, 443, 348-359 (1976)

2) Tasaka $Y$, Gombos $Z$, Nishiyama $Y$, Ohba T, Ohki K, Murata N : EMBO J., 15, 6416-6425 (1996)

3) Nakayama H, Ohki K, Mitsui T, Nozawa $Y$ : Biochim. Biophys. Acta, 769, 311-316 (1984)

4) Sinensky M : Proc. Nat. Acad. Sci. USA, 71, 522-525 (1974)

5) Nozawa Y, Iida H, Fukushima H, Ohki K, Ohnishi S : Biochim. Biophys. Acta, 367, 134-147 (1974)

6) Kameyama Y, Ohki K, Nozawa Y : J. Biochem., 88, 12911303 (1980)

7) Simons K, Ellina I : Nature, 387, 569-572 (1997)

8) Ipsen JH, Karlstrom G, Mouritsen OG, Wennerstrom H, Zuckermann MJ : Biochim. Biophys. Acta, 905, 162-172 (1987)

9) Keller SL, Pitcher WH III, W.H.Huestis WH, McConnell HM : Phys. Rev. Lett., 81, 5019-5022 (1998)

10) Silvius JR: Biochim. Biophys. Acta, 161 0, 174-183 (2003)

11) Guo $\mathrm{W}$, Kuze V, Huber T, Afdal NH, Beyer K, Hamilton JA : Biophys. J., 83, 1465-1478 (2002)

12) Taniguchi $\mathrm{Y}$, Ohba T, Miyata H, Ohki K : Biochm. Biophys. Acta, 1758, 145-153 (2006)

13) Nishizuka $Y$ : Science, 225, 1365-1370 (1984)

14) Berridge MJ : Biochem. J., 220, 345-360 (1984)

15) 和田多美子, 大小和夫: Membrane, 27, 331-386 (2002)

16) Parassi T, De Stasio G, Ravagnan G, Rusch RM, Gratton $\mathrm{E}$ : Biophys. J., 60, 179-189 (1971)

17) Ohba T, Tsuchiya S, Kumeta T, Ohki K : Jpn. J. Appl. Phys., 44, 8733-8738 (2005)

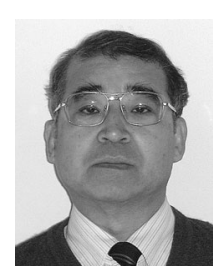

\section{著者略歴}

\section{大木 和夫（おおき かずお）}

1978年 6月 京都大学理学部, 同大 学院生物物理学専攻の 博士課程を修了（理学 博士）し, 日本学術振 興会特別研究員を経て, 岐阜大学医学部生化学 助手に, その後に同 講師

1986年 6 月 名古屋大学工学部応用 物理学科 助教授

1991 年 12 月 東北大学理学部物理学 科 教授

1995年 4 月 東北大学大学院理学研 究科物理学専攻 教授 に配置替え, 現在に 至る

1985～1986 年 文部省在外研究員と して米国ジョンス・ホ プキンス大学生物物理 学科に留学 